\title{
Artificial sociality in the human-machine interaction*
}

\author{
V. Komarova ${ }^{1}$, J. Lonska ${ }^{2}$, V. Tumalavičius ${ }^{1}$, A. Krasko ${ }^{1}$ \\ ${ }^{1}$ Daugavpils University \\ Vienibas St., 13, Daugavpils, LV-5401, Latvia \\ ${ }^{2}$ Rezekne Academy of Technologies \\ Atbrivosanas Alley, 115, Rezekne, LV-4601, Latvia \\ (e-mail: vera.komarova@du.lv; jelena.lonska@rta.lv; \\ vladas.tumalavicius@lka.lt; akrasko@inbox.lv)
}

\begin{abstract}
The article aims at clarifying the concept 'artificial sociality' in the humanmachine interaction by answering the question whether artificial sociality is a prerequisite or a result of this interaction. The authors conducted a logical analysis of the definitions of sociality and artificial sociality as presented in the scientific literature, and conducted an empirical study of artificial sociality in the human-machine interaction with three methods - comparison of means, correlation analysis and discriminant analysis. All three methods were used in the analysis of the same data: indicators of the potential of the human-machine interaction and G. Hofstede's six cultural dimensions. With these measurements of culture, the authors interpreted empirically the degree of its 'artificiality' (based on the methodological assumption about the combination of 'natural' and 'artificial' in culture) which determines the development of artificial sociality. Based on the results of the application of three methods of statistical analysis, the authors conclude that in the contemporary world, there are both conditionally 'artificial' cultures that are the most favourable for the development of artificial (algorithmic) sociality and conditionally 'natural' cultures that hinder the development of artificial sociality. This type of sociality emerged under the development of writing and various methods of processing and storing information (catalogues, archives, etc.), i.e., long before the creation of machines. Artificial sociality is determined by the relative 'artificiality' of culture, and is a prerequisite rather than a result of the human-machine interaction.
\end{abstract}

Key words: artificial sociality; human-machine interaction; G. Hofstede's cultural dimension; comparison of means; correlation analysis; discriminant analysis

The starting point for this study was a critical article by E.P. Tavokin [32] published in 2019 in response to the article by A.V. Rezaev and N.D. Tregubova published a year earlier [28]. Tavokin claims that "there is no 'artificial sociality' in nature and cannot exist at all: sociality can only be natural" [32]. Rezaev and Tregubova define artificial sociality [29] based on the approach of T. Malsch and his colleagues, who introduced this term: "a communication network in which,

* (C) V. Komarova, J. Lonska, V. Tumalavičius, A. Krasko, 2021

The article was submitted on 02.02.2021. The article was accepted on 02.04.2021. 
along with people, sometimes instead of people, other agents of artificial intelligence participate, and the Internet is the medium for their interaction" [22]. Rezaev and Tregubova claim to define artificial sociality 'more broadly' — as "the empirical fact of the participation of artificial intelligence agents in social interaction as its active mediators or participants" [29]. We used three methods comparison of means, correlation analysis and discriminant analysis - to analyse the same data - indicators of the potential of the human-machine interaction [34] and six cultural dimensions $[12 ; 15]$ - in order to identify empirically the degree of 'artificiality' of cultures, which determines the development of artificial sociality. Thus, methodology of the research presupposes (unlike Tavokin's theory) the presence of artificial sociality despite the lack of its clear theoretical definition (communication network [8; 22], fact of participation [27], etc.) and empirical interpretation.

\section{Interpretations of sociality - natural and artificial}

The main difficulty in comprehending artificial sociality is the lack of common understanding of the terms 'social' and 'sociality', which combines their natural and artificial manifestations. According to N. Luhmann, "even what is usually referred to as "social' has no unambiguously objective reference" [21]. At the same time, Luhmann separates mental systems (consciousness) from social systems (communication): "Man is a psychological phenomenon, but society and its subsystems are social" [20], and the challenge of our time is that machines are "becoming more and more social" [27;30].

Thus, the key concept for understanding sociality is communication (not consciousness or intelligence). "Communication is the smallest possible unit of a social system... Communication... is autopoietic if it can be produced in a recursive connection with other communications, that is, only in a network in the reproduction of which every single communication participates" [21]. Communication network can be quite extensive, and its agents - "along with people, sometimes instead of people" [22] — can be animals or machines capable of communication, i.e., social animals and social machines [4], or cognitive agents [2], social agents or social intelligence agents [4]. Consciousness ('thought feelings' [16] of mental systems) does not have a decisive significance for sociality: agents of the communication network do not have to feel, i.e., to somehow experience their social actions; moreover, sometimes feelings reduce the efficiency of actions: "Despite our vast knowledge of mathematics and computer science, we have not yet invented a single data processing system that requires subjective experiences to function, and not one that experiences pain, joy, anger or love" [9].

In order to define the concept of 'sociality', we need to distinguish between the terms 'sociality' and 'sociability' (while the notions 'social' and 'sociable' [agent] are identical [3]) by negation: sociality is not properties, abilities or attributes [1] of agents in the communication network. Sociality is a certain result of the implementation of all these properties, abilities and attributes in social 
interaction. Means of social interaction, created and used by communicating agents, are different: cooperation, rivalry, grouping, organization, etc. [4; 14]. We believe that "sociality expresses the social essence of people's life, the social specifics of their relationships and interactions" [7]. Thus, the 'social' in interactions leading to sociality is a pathway, method or mechanism which allows people (agents external to society, according to Luhmann) to ensure the functioning of the society as a social system they created. Thus, Luhmann defines the person not as an element of social system, but as a part of the world that ensures the functioning of social system [21].

To explain this method/mechanism of social interactions, G. Hofstede developed agent-based models (similar to system dynamics modeling for the study of complex systems [6:24]), or a method of social simulation [14;23] based on the idea of self-organization (autopoiesis) of all social systems. Hofstede wanted to understand how agents of the system interact and create its patterns [14], i.e., sociality is a pathway, method or mechanism of communication between agents people, animals and machines - in the self-organizing social system. Then social intelligence is a driving force of communication, and naturalness or artificiality are features of sociality as a pathway, method or mechanism of interaction between social intelligences. In other words, artificial way, method or mechanism of social interaction determines artificial sociality. There are many types of sociality natural [32], human $[16 ; 18 ; 28]$, animal $[16 ; 18]$ and artificial $[14 ; 27 ; 28 ; 30]$. According to Hofstede, "we have been obsessed with artificial intelligence, while forgetting artificial sociality" [14].

We consider artificial intelligence (more precisely, social intelligence participating in the communication network in some artificial way) as a determinant of artificial sociality, which is based on the works of Y. Harari. He argues that the invention of writing, then of classification, cataloguing, archiving and other methods for processing and storing information was the birth of artificial (algorithmic) intelligence which has nothing in common with the natural (associative) functioning of human brain (units of information are usually connected by associations and not logical connections). "When my wife and I go to the bank to sign a loan agreement for the purchase of a new home, we remember our first home, and from here the thread stretches to the honeymoon in New Orleans, and New Orleans is associated with crocodiles, crocodiles - with dragons, and this is direct way to the 'Ring of the Nibelung'. And suddenly, without realizing it, I start humming Siegfried's aria, but the bank clerk looks at me with surprise and confuses me, because in the bureaucratic system everything should be kept 'on its shelves"' [9].

Thus, the artificial intelligence of accounting, jurisprudence, librarianship, archiving and other activities in the increasingly complex social system, invented by people as 'servants' of their mind which once became a tool for the development of large and stable societies (cities, countries, empires), is turning into a 'master'. "Our computers do not understand well how we talk, feel and dream - and we are learning to speak, feel and dream in a computer-understandable language of 
numbers" [9]. Artificial intelligence is an attribute of both machines and people since the invention of writing and then the binary coding system. The development of artificial intelligence led to the emergence of artificial sociality as a means of communication of social agents based on the following algorithm: in system A, if we do B, then $\mathrm{C}$ happens [14] — and all these relationships can be understood, modelled and 'decomposed'. The artificial relationship is based on this algorithm as an unnatural, not typical-for-man way of interaction, which is the basis of artificial sociality. The very attempt to comprehend the place of artificial sociality among other terms and concepts is also a manifestation of artificial sociality as determined by the ability of human intelligence for algorithmic thinking, which developed long before the invention of machines but is comprehensible to machines and is 'spurred' today by their rapid development. The Figure 1 presents all the above in the scheme of artificial sociality based on Luhmann's model of communication [21].
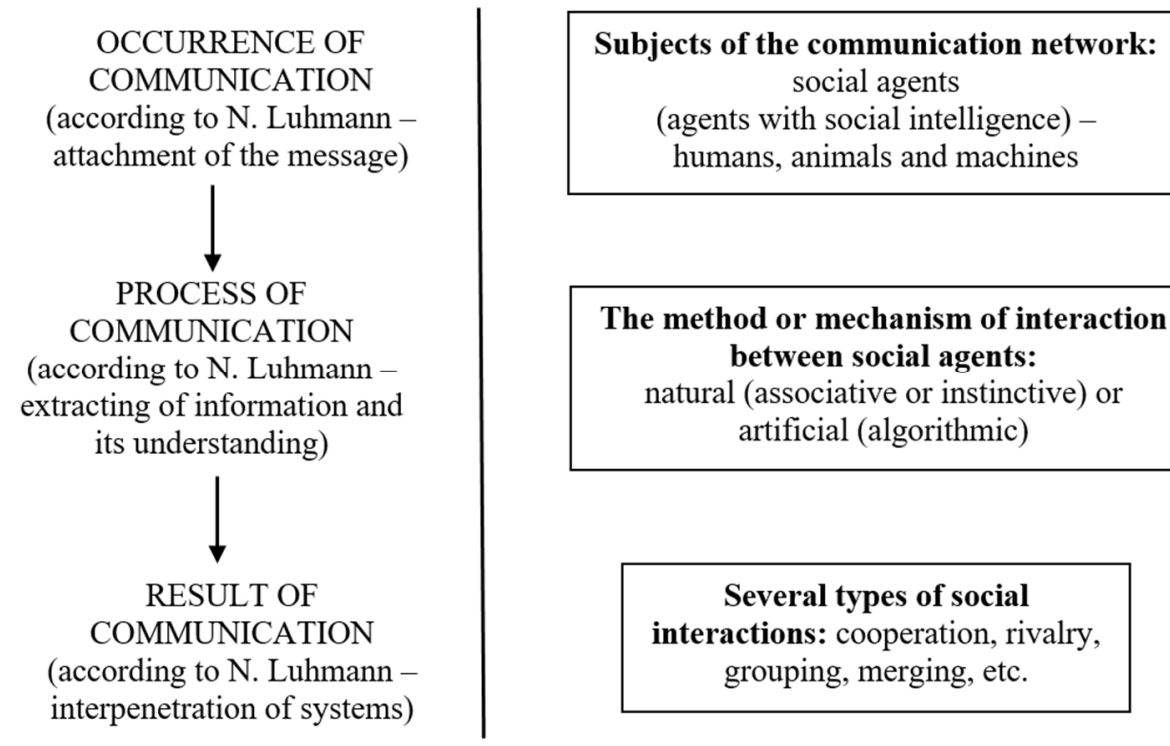
The method or mechanism of interaction between social agents:

natural (associative or instinctive) or artificial (algorithmic)

\section{Several types of social}

interactions: cooperation, rivalry, grouping, merging, etc.

Figure 1. Dynamic scheme of artificial (for people) sociality $[3 ; 4 ; 7 ; 9 ; 14 ; 20 ; 21 ; 22]$

Perhaps, art is one of the most important 'strongholds' of natural sociality in the world with an ever-increasing domination of artificial sociality. For instance, the great American artist M. Rothko believed that "ideally, an artist should express an inner sense of form without the intervention of mind. It is a physical and emotional experience, not an intellectual one" [26]. This is the natural human sociality in which "the object and the form lose their semantic load" [26]: person's reaction is determined by associations and senses, not by a formalized and structured algorithm of artificial sociality based on functional dependence (A causes B, and B causes C). The Russian psycholinguist T.V. Chernigovskaya mentioned that great discoveries in mathematics and physics first 'came' to their authors in the form of colour spots, sounds, and only then were written in symbols 
of artificial sociality (formulas). Today art researcher and educator M.S. Kazinik participates in the project of the School of Nobel Laureates - a system for developing children thinking as associative and interdisciplinary [17].

At first sociality became 'human' [18], in the contemporary world it becomes increasingly 'machine' due to losing its both 'bestial' and 'sublime' (i.e., irrational) nature (according to I.A. Khrzhanovsky, the director of the project Dau, - losing 'horror and beauty' as features of the natural human sociality). "Homo Sapiens will not be exterminated by rebellious robots. Most likely, he will gradually change himself, merging with robots and computers more and more, until our descendants look back and understand that they are not at all the creatures who wrote the Bible, built the Great Wall of China and laughed at Charlie Chaplin's films" [9].

\section{Methodology for the empirical study of artificial sociality}

To develop a methodology for the empirical study of artificial sociality in the human-machine interaction, we admit the combination of the 'natural' and 'artificial' in culture, and the latter as the basis for the development of artificial sociality. "When a patriotic bureaucrat accepts the best-qualified workers for highpaying positions, rather than his relatives or friends, then this is contrary to millions of years of evolution. Tax evasion and nepotism are natural for us, but nationalism calls it corruption. For people to condemn corruption and put national interests above family ties, countries have to maintain a huge apparatus that deals with education, propaganda and waving flags" [10]. "According to the universal law of least action, it is natural for people to economize on thinking, using ...convenient and familiar templates. Personal ties, dating between people are the basis of normal human communication and interaction" [19].

For the study of culture as a determinant of sociality — both natural or artificial we used G. Hofstede's model of six cultural dimensions as distinguishing countries (rather than individuals). The model consists of the following dimensions measured on the scale from 0 to 100 (in some cases, the upper score can exceed 100) [13]: Power Distance Index (PDI), Individualism vs Collectivism (IDV), Masculinity vs Femininity (MAS), Uncertainty Avoidance Index (UAI), Long Term Orientation vs Short Term Normative Orientation (LTO), Indulgence vs Restraint (IVR). Hofstede tried not to assess them in the 'naturalness-artificiality' perspective except one dimension - Indulgence vs Restraint, because Indulgence stands for "the basic and natural human drives associated with the enjoyment of life and fun" [13]. Thereby, in this model of national culture, 'natural' means a culture with a high level of indulgence of desires and a low level of social constraints.

The idea of using Hofstede's cultural dimensions for the study of other social phenomena is not new. For instance, in 2011, D.A. Coehlo published the results of the study of the relationship between production strategy, company size, national culture and innovativeness of companies in Europe [5], based on four 'classic' cultural dimensions - power distance, individualism-collectivism, masculinityfemininity, and uncertainty avoidance [11] (two other dimensions - LTO and 
IVR - were added to the model of national culture later, by Hofstede's colleagues [15]). Coelho made a conclusion that cultural dimensions have a moderate impact on the production strategy, company size and innovativeness; in countries with greater power distance, innovative companies are more likely to use technological rather than managerial innovations. However, we do not know about attempts to use Hofstede's cultural dimensions in the study of human-machine interaction.

For the empirical interpretation of the human-machine interaction we use the methodological approach developed and tested in the Daugavpils University [25] - it measures the potential of the human-machine interaction with two indicators (for higher stability of measurement): ICT (Information and Communication Technology) adoption and digital skills of the active population (provided by the World Economic Forum for more than a hundred countries on the scale from 0 to 100 [34]). Although these indicators do not show directly the level of the human-machine interaction in the country, the high score of two indicators indicates the high potential in this field [25]. Thus, the two indicators - ICT adoption and digital skills of the active population - are not sufficient but necessary for the development of the human-machine interaction, i.e., together they indicate at least the potential for the human-machine interaction in the country [25].

Table 1 presents two levels of the empirical analysis of the potential of the human-machine interaction - general and intergroup. We suggest that countries with a high potential will differ statistically significantly — by all or several cultural dimensions - from countries with a low potential, which will prove that artificial sociality, to a large extent determined by 'artificiality' of culture, helps to increase the potential of the human-machine interaction. To test this hypothesis, we used three methods on the same data for 63 countries: comparison of means (of cultural dimensions in the groups of countries with the high and low potential); correlation analysis (to estimate the strength and statistical significance of the relationships between cultural dimensions and the potential of the human-machine interaction); discriminant analysis (to identify the 'discriminatory' cultural dimensions in order to predict the country's group).

Table 1

Two levels of the analysis of the potential of the human-machine interaction

\begin{tabular}{|c|c|c|}
\hline General level & $\begin{array}{r}\text { The sample of countries for which data is available for both indicators: } \\
\text { ICT adoption and digital skills of the active population }\end{array}$ \\
\hline Intergroup level & High potential & Low potential \\
\hline ICT adoption & Above the sample mean & Below the sample mean \\
\hline Digital skills & Above the sample mean & Below the sample mean \\
\hline
\end{tabular}

Note: countries with one indicator above and another indicator below the sample average were excluded from the intergroup level as 'non-pure' types

The results of the comparison of means for the six cultural dimensions in the groups with different potential of the human-machine interaction are presented in Table 2. 
Mean values of cultural dimensions in groups of countries with different potential of the human-machine interaction, 2019 [12; 34]

\begin{tabular}{|c|c|c|c|c|}
\hline $\begin{array}{c}\text { Cultural } \\
\text { dimensions }\end{array}$ & $\begin{array}{c}\text { Sample } \\
\mathbf{( 6 3 )}\end{array}$ & $\begin{array}{c}\text { High potential } \\
\mathbf{( 3 1 )}\end{array}$ & $\begin{array}{c}\text { Low potential } \\
\mathbf{( 2 3 )}\end{array}$ & $\mathbf{p}$ \\
\hline $\begin{array}{c}\text { Power Distance Index } \\
\text { (PDI) }\end{array}$ & 59 & 51 & 33 & $\begin{array}{c}0.008 \text { (statistically } \\
\text { significant) }\end{array}$ \\
\hline $\begin{array}{c}\text { Individualism vs } \\
\text { Collectivism (IDV) }\end{array}$ & 46 & 57 & 53 & 0.000 (significant) \\
\hline $\begin{array}{c}\text { Masculinity vs } \\
\text { Femininity (MAS) }\end{array}$ & 49 & 46 & 75 & 0.254 (insignificant) \\
\hline $\begin{array}{c}\text { Uncertainty Avoidance } \\
\text { Index (UAI) }\end{array}$ & 67 & 57 & 36 & 0.000 (significant) \\
\hline $\begin{array}{c}\text { Long Term vs Shor } \\
\text { Term Normative } \\
\text { Orientation (LTO) }\end{array}$ & 49 & 49 & 49 & 0.993 (insignificant) \\
\hline $\begin{array}{c}\text { Indulgence vs } \\
\text { Restraint (IVR) }\end{array}$ & 49 & & & \\
\hline
\end{tabular}

Countries with a high potential of the human-machine interaction have higher indicators in four cultural dimensions - PDI, IDV, UAI, and LTO; while in MAS and especially IVR, there is no statistically significant difference between groups with the high and low potential, Thus, MAS and IVR are not statistically significant for the human-machine interaction and do not contribute to the dissemination of the artificial (algorithmic) means of social agents interaction (Fig. 1), i.e., these two cultural dimensions are not decisive for the development of artificial sociality.

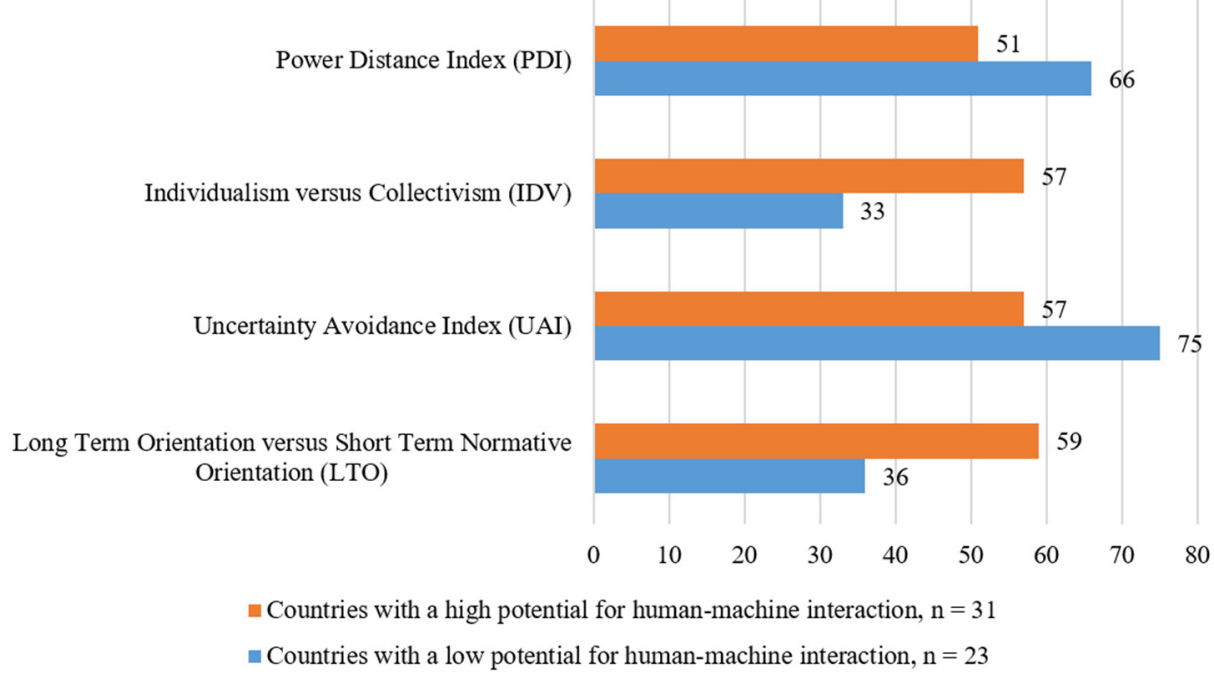

Figure 2. Statistically significant differences in cultural dimensions in two groups of countries

In order to verify the results of the comparison of means, we conducted the correlation analysis of cultural dimensions and indicators of the potential of the human-machine interaction for the sample of 63 countries not divided in groups with different potential (Table 3). 
Table 3

Cultural dimensions and potential of the human-machine interaction (Pearson), 2019

\begin{tabular}{|c|c|c|}
\hline \multirow{2}{*}{ Cultural dimensions } & \multicolumn{2}{|c|}{ Indicators } \\
\hline & ICT adoption & Digital skills \\
\hline Power Distance Index (PDI) & 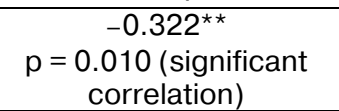 & 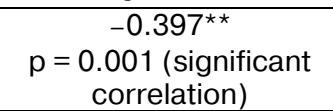 \\
\hline Individualism vs Collectivism (IDV) & $\begin{array}{c}+0.386^{\star \star} \\
\mathrm{p}=0.002 \text { (significant) }\end{array}$ & $\begin{array}{c}+0.462^{\star \star} \\
\mathrm{p}=0.000 \text { (significant) }\end{array}$ \\
\hline Masculinity vs Femininity (MAS) & $\begin{array}{c}-0.209 \\
p=0.100 \text { (insignificant) }\end{array}$ & $\begin{array}{c}-0.186 \\
p=0.144 \text { (insignificant) }\end{array}$ \\
\hline Uncertainty Avoidance Index (UAI) & $\begin{array}{c}-0.189 \\
p=0.139 \text { (insignificant) }\end{array}$ & $\begin{array}{c}-0.506^{\star \star} \\
p=0.000 \text { (significant) }\end{array}$ \\
\hline $\begin{array}{l}\text { Long Term vs Short Term } \\
\text { Normative Orientation (LTO) }\end{array}$ & $\begin{array}{c}+0.461^{\star \star} \\
\mathrm{p}=0.000 \text { (significant) }\end{array}$ & $\begin{array}{c}+0.285^{\star} \\
p=0.024 \text { (significant) }\end{array}$ \\
\hline Indulgence vs Restraint (IVR) & $\begin{array}{c}-0.004 \\
p=0.976 \text { (insignificant) }\end{array}$ & $\begin{array}{c}0.075 \\
p=0.559 \text { (insignificant) }\end{array}$ \\
\hline
\end{tabular}

* Statistically significant correlation (with $95 \%$ probability)

** Statistically significant correlation (with $99 \%$ probability)

The results of the correlation analysis confirmed the results of the comparison of means, and two cultural dimensions - MAS and especially IVR — do not show the statistically significant correlation with the indicators of the potential of the human-machine interaction. The other four cultural dimensions (except for UAI in relation to the ICT adoption) showed statistically significant moderate relations with both indicators, i.e., proved their importance for the development of artificial sociality. Despite the fact that in the mathematical sense, the correlation means a two-way relationship of variables, the Figure 3 shows the one-way statistically significant relationships - cultural dimensions affect indicators of the humanmachine interaction.
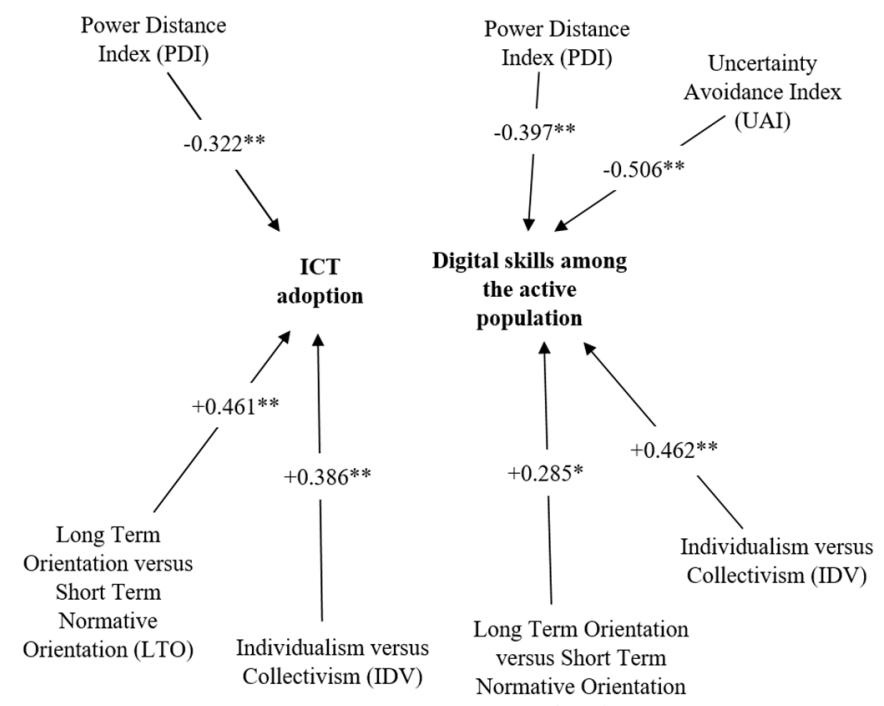

(LTO)

Figure 3. Statistically significant influences of cultural dimensions on indicators of the country's potential of the human-machine interaction (Pearson Correlation, 63 countries) 
We used the discriminant analysis to identify the cultural dimensions whose 'discriminating' power determines the group of the potential for the country. At first, we tested the very possibility of the discriminant analysis on the sample of 63 countries based on the eigenvalues (the correlation coefficient between the calculated values of the discriminant function and actual group membership is 0.767 , which is satisfactory [13]) and the Wilks' Lambda (the mean values of the discriminant function differ significantly in both groups - $(p<0.001))$. The results of the discriminant analysis in Table 4 prove the accuracy of predictions and the statistical significance ('discriminant power') of all potentially 'discriminatory' cultural dimensions (Table 5). Thus, from 31 countries with a high potential of the human-machine interaction, 28 were correctly predicted to be in this group $(90.3 \%)$, while 3 countries were mistakenly included in this group. In the group with a low potential of the human-machine interaction, 4 countries were mistakenly included, while 19 countries do belong to this group (82.6\%). Therefore, the applied model of the discriminant analysis more accurately predicts the country's group with the high potential.

Table 4

Results of the discriminant analysis

\begin{tabular}{|c|c|c|c|}
\hline \multicolumn{2}{|c|}{ Units and groups } & \multicolumn{2}{|c|}{ Predicted potential } \\
\hline Units & Groups & $\begin{array}{c}\text { Countries with } \\
\text { a high potential of the } \\
\text { human-machine interaction }\end{array}$ & $\begin{array}{l}\text { Countries with a low potential } \\
\text { of the human-machine } \\
\text { interaction }\end{array}$ \\
\hline \multirow{3}{*}{ Numbers } & $\begin{array}{l}\text { Countries with a high } \\
\text { potential }\end{array}$ & 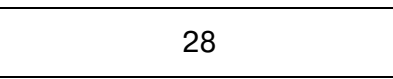 & 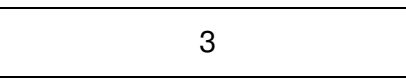 \\
\hline & $\begin{array}{l}\text { Countries with a low } \\
\text { potential }\end{array}$ & 4 & 19 \\
\hline & Ungrouped cases* & 3 & 6 \\
\hline \multirow{3}{*}{$\%$} & $\begin{array}{l}\text { Countries with a high } \\
\text { potential }\end{array}$ & 90.3 & 9.7 \\
\hline & $\begin{array}{l}\text { Countries with a low } \\
\text { potential }\end{array}$ & 17.4 & 82.6 \\
\hline & Ungrouped cases & 33.3 & 66.7 \\
\hline
\end{tabular}

* These are those 9 countries in which one indicator of the potential of the human-machine interaction is higher than the sample mean, and the other is lower; therefore, they do not belong to any group

The main result of the discriminant analysis is the average level of correctness of predictions for both groups: $28+19=47$ countries' group was correctly predicted, which is $87 \%$ ( 47 out of 54 countries included in the analysis). This is a high correctness level [31]: in $87 \%$ of cases, it is possible to assess the country's potential of the human-machine interaction by its cultural dimensions. To check which cultural dimensions allow to immediately say (with $87 \%$ probability) in which of two groups a country will be included, we made Table 5 showing the statistical significance (real 'discriminant power') of the cultural dimensions used in the discriminant analysis. 
Statistical significance of cultural dimensions

\begin{tabular}{|c|c|c|c|c|}
\hline Cultural dimensions & $\begin{array}{c}\text { Mann-Whitney } \\
\mathbf{U}\end{array}$ & Wilcoxon W & $\begin{array}{c}\text { Standardized } \\
\text { value } \mathbf{Z}\end{array}$ & $\begin{array}{c}\text { Statistical } \\
\text { significance }\end{array}$ \\
\hline $\begin{array}{c}\text { Power Distance Index } \\
\text { (PDI) }\end{array}$ & 188.5 & 684.5 & -2.94 & 0.003 \\
\hline $\begin{array}{c}\text { Individualism vs } \\
\text { Collectivism (IDV) }\end{array}$ & 157.5 & 433.5 & -3.484 & 0 \\
\hline $\begin{array}{c}\text { Masculinity vs Femininity } \\
\text { (MAS) }\end{array}$ & 310 & 806 & -0.814 & 0.416 \\
\hline $\begin{array}{c}\text { Uncertainty Avoidance } \\
\text { Index (UAI) }\end{array}$ & 182. & 678 & -3.054 & 0.002 \\
\hline $\begin{array}{c}\text { Long Term vs Short Term } \\
\text { Normative Orientation } \\
\text { (LTO) }\end{array}$ & 157.5 & 433.5 & -3.482 & 0 \\
\hline $\begin{array}{c}\text { Indulgence vs Restraint } \\
\text { (IVR) }\end{array}$ & 346 & 622 & -0.184 & 0.854 \\
\hline
\end{tabular}

Note: the grouping variable is the high or low potential of the human-machine interaction

According to Table 5, like in the comparison of means and in the correlation analysis, two dimensions of culture — MAS and IVR) — are not statistically significant for predicting the country's potential of the human-machine interaction. In the contrary, PDI $(p=0.003)$, UAI $(p=0.002)$, and especially IDV and LTO $(\mathrm{p}=0)$ are those 'discriminatory' variables that determine this potential.

Based on the results of all three methods of the statistical analysis, we can conclude that there are conditionally 'artificial' cultures that are the most favourable for the development of artificial (algorithmic) sociality and conditionally 'natural' cultures that hinder the development of artificial sociality. Table 6 presents the main features and examples of both types of culture.

Table 6

Key features and examples of conditionally 'artificial' and 'natural' cultures

\begin{tabular}{|l|l|l|l|}
\hline \multicolumn{2}{|c|}{ 'Artificial' } & \multicolumn{1}{c|}{ 'Natural' } \\
\hline \multicolumn{1}{|c|}{ Features } & \multicolumn{1}{|c|}{ Leaders } & \multicolumn{1}{c|}{ Features } & \multicolumn{1}{c|}{ Leaders } \\
\hline Small power distance & $\begin{array}{l}\text { Austria (11) } \\
\text { Denmark (18) } \\
\text { New Zealand (22) }\end{array}$ & Big power distance & $\begin{array}{l}\text { Malaysia (104) } \\
\text { Philippines (94) } \\
\text { Russia (93) }\end{array}$ \\
\hline Individualism & $\begin{array}{l}\text { USA (91) } \\
\text { Australia (90) } \\
\text { United Kingdom (89) }\end{array}$ & Collectivism & $\begin{array}{l}\text { Venezuela (12)* } \\
\text { Columbia (13) } \\
\text { Indonesia, Pakistan } \\
\text { (14) }\end{array}$ \\
\hline $\begin{array}{l}\text { Uncertainty } \\
\text { acceptance }\end{array}$ & $\begin{array}{l}\text { Singapore (8) } \\
\text { Denmark (23) } \\
\text { Hong Kong (29) }\end{array}$ & Uncertainty avoidance & $\begin{array}{l}\text { Greece (112) } \\
\text { Portugal (104) } \\
\text { Malta (96) }\end{array}$ \\
\hline $\begin{array}{l}\text { Long term (pragmatic) } \\
\text { orientation }\end{array}$ & $\begin{array}{l}\text { South Korea (100) } \\
\text { Japan (88) } \\
\text { China (87) }\end{array}$ & $\begin{array}{l}\text { Short term } \\
\text { (normative) } \\
\text { orientation }\end{array}$ & $\begin{array}{l}\text { Columbia, Trinidad } \\
\text { and Tobago (13)*** } \\
\text { Iran, Morocco (14) } \\
\text { Venezuela (16) }\end{array}$ \\
\hline
\end{tabular}

* The score corresponds to a relatively low level of individualism

** The score corresponds to a relatively low level of uncertainty avoidance

$\star \star \star$ The score corresponds to a relatively low level of long term (pragmatic) orientation 
Since Denmark and Venezuela are the leaders of, respectively, conditionally 'artificial' and 'natural' culture twice (according to two cultural dimensions each), they can be considered the most typical representatives of these culture. Figure 4 presents the comparison of the 'discriminatory' cultural dimensions and indicators of the potential of the human-machine interaction for Denmark and Venezuela. Both countries demonstrate large differences not only in the 'discriminatory' cultural dimensions, but also in the indicators of the potential of the human-machine interaction. For instance, the level of ICT adoption in Denmark is twice higher than in Venezuela (82 vs 43), and the digital skills of the active population in Denmark is also almost twice higher than in Venezuela (72 vs 44). Thus, Denmark and Venezuela can be considered as an example that the 'artificiality'/"naturalness' of culture (determining the development of the corresponding types of sociality) is a significant factor of the potential of the human-machine interaction.

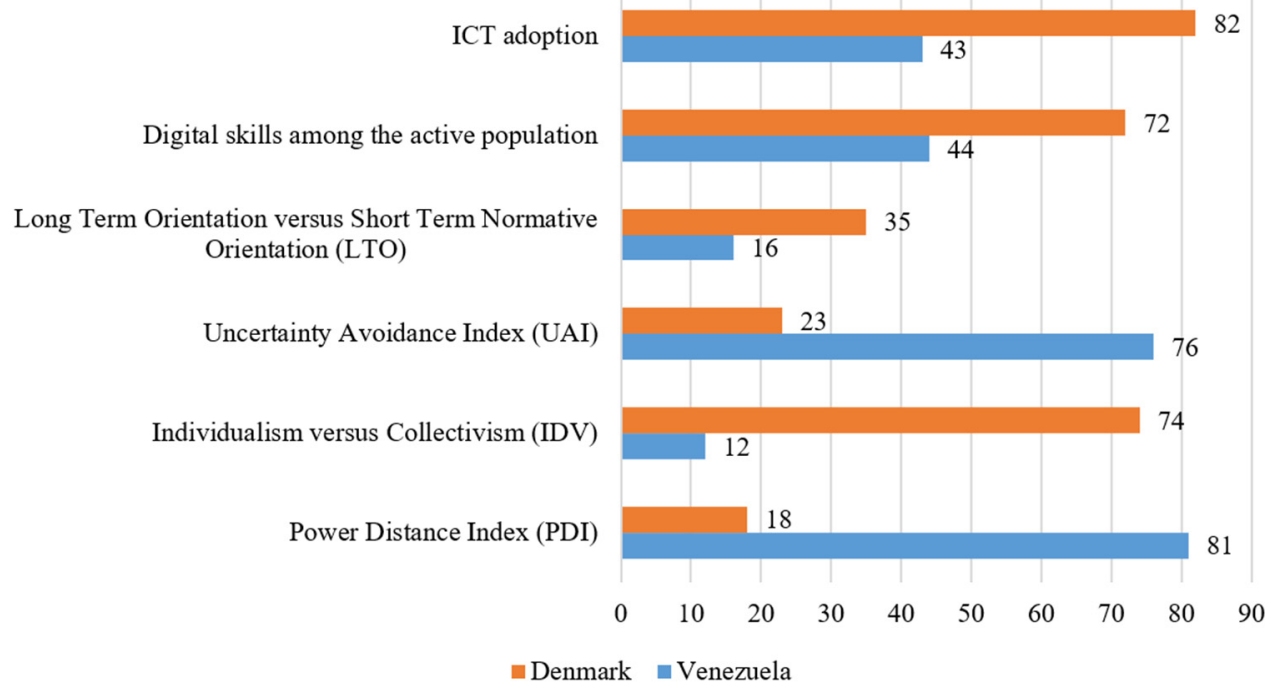

Figure 4. Denmark' and Venezuela' scores of the 'discriminatory' cultural dimensions and indicators of the potential of the human-machine interaction

Thus, we can conclude that sociality is not properties of agents in the communication network, but a result of the implementation of these properties in social interactions created and used by communicating agents. Artificial sociality presupposes artificial (algorithmic) as opposed to natural (associative or intuitive) means of interaction between social agents due to the development of various methods of processing and storing information long before the appearance of machines. Artificial sociality is determined by the conditional 'artificiality' of culture and is a prerequisite, not a result of the human-machine interaction. Therefore, the 'artificiality' of culture is a decisive factor of the potential of the human-machine interaction.

\section{Funding}

The research was supported by the Erasmus+ Program of the European Union Eurokey. Project No. 2017-1-TR01-KA202-046115. 


\section{References}

[1] Antinazi A. Sociabelnost [Sociability]. Entsiklopediya sociologii. URL: http://sociology.niv.ru/ doc/encyclopedia/socio/fc/slovar-209-2.htm\#zag-3769. (In Russ.).

[2] Castelfranchi C. Guaranties for autonomy in cognitive agent architecture. Woolridge M., Jennings N. (Eds.). Intelligent Agents I. Berlin; 1995.

[3] Castelfranchi C. Individual social action. Holmstrom-Hintikka G., Tuomela R. (Eds.). Contemporary Action Theory. Vol. 2: Social Action. Springer; 1997.

[4] Castelfranchi C. Modelling social action for AI agents. Artificial Intelligence. 1998; 103 (1-2).

[5] Coelho D. A study on the relation between manufacturing strategy, company size, country culture and product and process innovation in Europe. International Journal of Business and Globalisation. 2011; 7 (2).

[6] Currie D., Smith C., Jagals P. The application of system dynamics modelling to environmental health decision-making and policy - a scoping review. BMC Public Health. $2018 ; 18$.

[7] Elsukov A. Sotsiologija [Sociology]. Minsk; 2014. (In Russ.).

[8] Fischer K., Florian M., Malsch T. (Eds.). Socionics: Scalability of Complex Social Systems. Berlin-Heidelberg; 2005.

[9] Harari Y. Homo Deus: A Brief History of Tomorrow. Harvill Secker; 2016.

[10] Harari Y. 21 Lessons for the $21^{\text {st }}$ Century. Spiegel \& Grau; 2018.

[11] Hofstede G. Culture's Consequences: Comparing Values, Behaviours, Institutions and Organizations Across Countries. Thousand Oaks; 2001.

[12] Hofstede G. 6 dimensions for website.xls. Dimension Data Matrix. URL: https://geerthofstede.com/research-and-vsm/dimension-data-matrix.

[13] Hofstede G. Dimensions of National Culture. URL: https://hi.hofstede-insights.com/ national-culture.

[14] Hofstede G.J. Artificial Sociality: Simulating the Social Mind. URL: https://geerthofstede.com/ wp-content/uploads/2019/05/Oratieboekje_Hofstede_Artif-Sociality-2019-01-17.pdf.

[15] Hofstede G., Hofstede G.J, Minkov M. Cultures and Organizations: Software of the Mind. McGraw Hill Professional; 2010.

[16] Kamenets A. Kulturologiya russkogo mira: dukhovnye osnovy natsionalnogo mentaliteta [Culturology of the Russian World: Spiritual Foundations of the National Mentality]. Moscow; 2016. (In Russ.).

[17] Kazinik M. Shkola Nobelevskih laureatov [School of Nobel laureates]. URL: http://kazinik.ru/ documents/d8eaeeebe0_cdeee1e5ebe5e2fleae8f5_ebe0f3f0e5e0f2ee.html. (In Russ.).

[18] Krasavin I. Fraktalnaya istoriya [Fractal Story]. Moscow; 2015. (In Russ.).

[19] Lebedev S. Belgorod - gorod "kumovstva" i "svjazej" [Belgorod is a city of "nepotism" and "connections"]. URL: https://fonar.tv/article/2019/03/15/belgorod-gorod-kumovstva-isvyazey-sociolog-sergey-lebedev-o-populyarnyh-belgorodskih-stereotipah. (In Russ.).

[20] Luhmann N. Social Systems. Palo Alto; 1995.

[21] Luhmann N. Introduction to Systems Theory. Polity Press; 2013.

[22] Malsch T. (Ed.) Sozionik - Soziologische Ansichten uber kunstliche Sozialitat. Berlin; 1998.

[23] Malsch T. Naming the unnamble: Socionics or the sociological turn of/to Distributed Artificial Intelligence. Autonomous Agents and Multi-Agent Systems. 2001; 4 (3).

[24] McKelvie D. Modelling Social Care Complexity: The Potential of System Dynamics. London; 2013.

[25] Menshikov V., Kokina I., Komarova V., Korshenkov E. Human-machine collaboration as a factor of labour productivity and efficiency. European Scientific Journal. 2020; 16 (13).

[26] Ottmann K. The Essential Mark Rothko. New York; 2003.

[27] Rezaev A., Starikov V., Tregubova N. Sociologija v epohu "iskusstvennoj sotsialnosti": poisk novyh osnovanij [Sociology in the era of "artificial sociality": The search for new foundations]. Sotsiologicheskie Issledovanija. 2020; 2. (In Russ.). 
[28] Rezaev A., Tregubova N. Are sociologists ready for 'artificial sociality'? Current issues and future prospects for studying artificial intelligence in social sciences. Monitoring of Public Opinion: Economic and Social Changes. 2018; 5.

[29] Rezaev A., Tregubova N. "Iskusstvenny intellekt", “onlain-kultura”, “iskusstvennaja sotsialnost": opredelenie ponjatij ['Artificial intelligence', 'online culture', 'artificial sociality': Definition of the terms]. Monitoring of Public Opinion: Economic and Social Changes. 2019; 6. (In Russ.).

[30] Rezaev A., Tregubova N., Starikov V. Sociological considerations on human-machine interactions: From artificial intelligence to artificial sociality. Proceedings of the International Conference on Industry, Business and Social Sciences. URL: https://pureportal.spbu.ru/en/ publications/sociological-considerations-on-human-machine-interactions-from-ar.

[31] Sweet S., Grace-Martin K. Data Analysis with SPSS: A First Course in Applied Statistics. Pearson; 2012.

[32] Tavokin E. Iskusstvennost "iskusstvennoj sotsia'nosti" [The artificiality of "artificial sociality']. Sotsiologicheskie Issledovanija. 2019; 6. (In Russ.).

[33] University of Surrey: Journal of Artificial Societies and Social Simulation. URL: http://jasss.soc.surrey.ac.uk/JASSS.html.

[34] World Economic Forum. The Global Competitiveness Report 2019. Schwab K. (Ed.). Geneva; 2019.

DOI: $10.22363 / 2313-2272-2021-21-2-377-390$

\title{
Искусственная социальность в человеко-машинном взаимодействии*
}

\author{
В. Комарова ${ }^{1}$, Е. Лонская ${ }^{2}$, В. Тумалавичюс ${ }^{1}$, А. Краско ${ }^{1}$ \\ ${ }^{1}$ Даугавпилсский университет \\ ул. Виенибас, 13, Даугавпилс, LV-5401, Латвия \\ ${ }^{2}$ Резекненская академия технологий \\ аллея Атбривошанас, 115, Резекне, LV-4601, Латвия \\ (e-mail: vera.komarova@du.lv; jelena.lonska@rta.lv; \\ vladas.tumalavicius@lka.lt; akrasko@inbox.lv)
}

\begin{abstract}
Аннотация. Цель статьи - прояснить суть понятия «искусственная социальность» применительно к человеко-машинному взаимодействию, ответив на вопрос, является ли искусственная социальность предпосылкой или результатом этого взаимодействия. Для достижения поставленной цели авторы провели логический анализ определений социальности и искусственной социальности в научной литературе, а также эмпирически изучили искусственную социальность в человеко-машинном взаимодействии с помощью трех методов - сравнения средних, корреляционного анализа и дискриминантного анализа. Все три метода применялись для анализа одних и тех же данных: показателей потенциала взаимодействия людей и машин и шести культурных измерений, разработанных Г. Хофстеде. С помощью этих культурных измерений авторы попытались эмпирически интерпретировать степень «искусственности» культуры, опираясь на методологический принцип,
\end{abstract}

* ( С Комарова В., Лонская Е., Тумалавичюс В., Краско А., 2021

Статья поступила 02.02.2021 г. Статья принята к публикащии 02.04.2021 г. 
утверждающий сочетание «естественного» и «искусственного» в любой культуре. Результаты эмпирического анализа позволили авторам сделать вывод, что в современном мире существуют условно «искусственные» культуры, наиболее благоприятные для развития искусственной (алгоритмической) социальности, а также условно «естественные» культуры, препятствующие развитию данного типа социальности. Искусственная социальность начала оформляться в обществе вместе с созданием письменности, а затем развивалась по мере появления различных методов обработки и хранения информации (каталоги, архивы и т.п.), т.е. искусственная социальность появилась задолго до изобретения машин. Таким образом, искусственная социальность обусловлена «искусственностью» культуры и является предпосылкой, а не результатом человеко-машинного взаимодействия.

Ключевые слова: искусственная социальность; человеко-машинное взаимодействие; культурные измерения по Г. Хофстеде; метод сравнения средних; корреляционный анализ; дискриминантный анализ 